Article

\title{
Approach to Urban Environmental Justice Using Exploratory Spatial Data Analysis. The Case of Valencia's Monumental Trees
}

\author{
Alfonso Gallego-Valadés $\left({ }^{\circledR}\right.$, Francisco Ródenas-Rigla * ${ }^{\mathbb{C}}$ and Jorge Garcés-Ferrer \\ Polibienestar Research Institute, University of Valencia, Carrer del Serpis, 29, 46022 Valencia, Spain; \\ alfgallev@gmail.com (A.G.-V.); jordi.garces@uv.es (J.G.-F.) \\ * Correspondence: francisco.rodenas@uv.es
}

Received: 28 August 2020; Accepted: 17 September 2020; Published: 19 September 2020

check for updates

\begin{abstract}
Environmental justice has been a relevant object of analysis in recent decades. The generation of patterns in the spatial distribution of urban trees has been a widely addressed issue in the literature. However, the spatial distribution of monumental trees still constitutes an unknown object of study. The aim of this paper was to analyse the spatial distribution of the monumental-tree heritage in the city of Valencia, using Exploratory Spatial Data Analysis (ESDA) methods, in relation to different population groups and to discuss some implications in terms of environmental justice, from the public-policy perspective. The results show that monumental trees are spatially concentrated in high-income neighbourhoods, and this fact represents an indicator of environmental inequality. This diagnosis can provide support for decision-making on this matter.
\end{abstract}

Keywords: environmental justice; urban trees; spatial distribution

\section{Introduction}

Environmental justice refers to the principle by which environmental costs and benefits must be equitably distributed among the population [1]. In the urban context, environmental justice depends on the level of equity in the spatial distribution of costs and benefits to the population groups that make up the socio-residential structure of the city. This distribution depends mainly on the territorialized implementation of green intervention policies and their link with the socio-spatial and residential structure of the population.

Environmental justice has been a relevant object of analysis in recent decades, as a consequence of the growing prominence of green issues on the urban agenda. Much of the research has focused on issues such as the accessibility and spatial distribution of green infrastructure, and its relationship with the socio-residential composition of neighbourhoods. As a key part of the urban green infrastructure, the generation of patterns in the spatial distribution of urban trees has been a widely addressed issue in the literature [2-8]. Urban trees provide several ecosystem benefits, such as temperature regulation $[9,10]$, air-pollution reduction [11], stormwater-runoff control [12] or preserving biodiversity [13], among others. Urban trees can also provide social benefits by contributing to the physical and psychological health of citizens and community economic development [14]. However, the spatial distribution of urban monumental trees still constitutes an unknown object of study, despite its remarkable singularity and great botanical, cultural, symbolic or landscape value.

The approval, in 2006, of the law on the monumental-tree heritage of the Valencian Community involved the implementation of a pioneering legislative framework for the protection and management of monumental trees. The law defines as monumental-tree heritage the set of trees whose botanical characteristics of monumentality or extraordinary circumstances of age; size; or other types of 
historical, cultural, scientific, recreational or environmental events linked to them and their legacy make them worthy of protection and conservation. It is applied to the specimens of higher plants, both angiosperms and gymnosperms, autochthonous or allochthonous, that have one or more sufficiently differentiated trunks. This concept applies equally to trees with horizontal or creeping growth, palm trees, certain shrubs and the thick trunk shapes of lianas or climbing plants.

The law established a generic protection framework for trees that meet at least some of the specified criteria regarding age and size: 350 years old, $30 \mathrm{~m}$ high, $6 \mathrm{~m}$ of trunk perimeter (measured at a height of $1.30 \mathrm{~m}$ from the base), or $25 \mathrm{~m}$ of greater diameter of the canopy (measured in projection on the horizontal plane). Generic protection is also established for the different species of the Palmae family that exceed $12 \mathrm{~m}$ in stipe, with the exception of Washingtonia robusta H.A. Wendland, whose threshold is set at $18 \mathrm{~m}$. The specimens declared invasive by the regulations are not included when they are a source of dispersal to the natural environment.

The management of monumental trees is carried out at two levels of government. The regional government is the main responsible entity for the protection and cataloguing of the trees. However, the responsibility to propose the inclusion of the candidate specimens in the Catalogue of Monumental and Singular Trees of the Valencian Community falls to local governments. Local governments also have some responsibilities in the protection of monumental trees.

Alternatively, competences were instituted for both regional and local governments in mechanisms for the express protection of monumental trees. Apart from this generic protection framework, municipalities can declare monumental trees of local interest for those specimens or arboreal groups that stand out at the local level due to their biological, landscape, historical, cultural or social characteristics and that are made deserving of protection and conservation policies. Municipalities must communicate this statement to the regional government for inclusion in the appropriate section of the catalogue of monumental trees. At the same time, some municipalities have established their own protection mechanisms that follow the same pattern set by regional legislation. This is the case of the city of Valencia, which has its own local-interest-tree catalogue, with trees not included in the regional catalogue.

Monumental and singular trees offer numerous possibilities within the field of environmental education and sustainable development. The extraordinary characteristics of these trees confer greater tourist [15], residential, educational and environmental attractiveness to the environments in which they are located and allow promoting the sustainable development of these places. Analogously, uneven spatial distribution patterns for these trees would imply negative consequences in terms of environmental justice.

The aim of this paper is to analyse the spatial distribution of the monumental-tree heritage in the city of Valencia, in relation to different population groups, and to discuss some implications in terms of environmental justice, from the public-policy perspective.

\section{Materials and Methods}

\subsection{Study Area}

Valencia (Figure 1) is the capital of the Valencian Community and of the province of the same name. Its urban region encompasses a total of 45 municipalities [16]. According to data from the Statistic National Institute (INE) for 2017, it has a total of 787,808 inhabitants and an approximate area of $134.65 \mathrm{~km}^{2}$, being the third-largest municipality in Spain by population and the largest in its autonomous community. The municipality is territorially articulated with a total of 19 districts, 88 neighbourhoods and 596 census sections (Supplementary Materials Shapefile S1). 


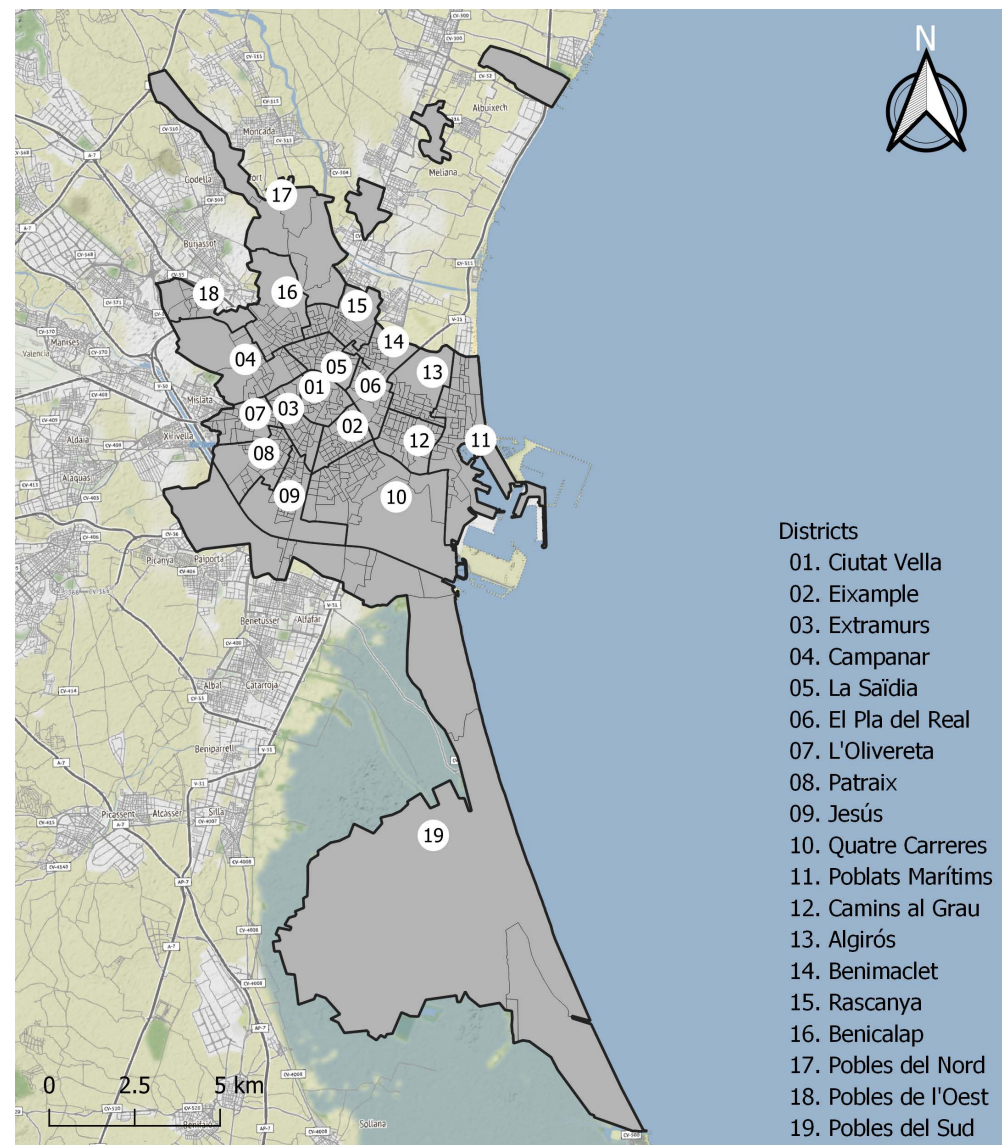

Figure 1. Valencia's municipal boundaries and census districts.

From the middle of the 20th century, coinciding with the beginning of the development phase, until today, Valencia has undergone a remarkable process of social and urban transformation. In this period, the city has gone from having an agricultural sector with a significant weight in the productive structure to becoming a service metropolis and a cultural and tourist enclave with international projection $[17,18]$. This transition has been accompanied, since the 1990s, by various processes of tourist and commercial gentrification in deprived neighbourhoods, mainly led by the local government [17-22]. Green infrastructure has played a significant role in this transformation process. Let us note, as an example, the conversion of the old Turia riverbed into a green corridor that crosses the city from the extreme west to the historic basin of the port of Valencia, despite the initial plan to occupy this space with transport infrastructure.

The approval of the regulations on monumental-tree heritage, in 2006, has favoured the gradual incorporation into the Catalogue of Monumental and Singular Trees of the Valencian Community of 352 specimens subject to generic protection, located in the municipality of Valencia. Outside this protection scheme are the trees and arboreal groups of local interest, expressly declared by the city council. In this work, we consider the 352 specimens subject to generic protection included in the catalogue, and 165 trees declared of local interest (Shapefiles S2-S4).

Figure 2 (top left) shows the spatial distribution of these trees, located both in urban roads and in green spaces. Figure 2 (top right) presents the values of the gaussian kernel density estimates of all the trees (Table S1), with bandwidth selection based on the likelihood cross-validation criterion proposed by Duin [23] and Habbema et al. [24]. The colour scale fluctuates between dark green (indicating maximum locational density) and yellow (indicating lower density). The areas without chromatic assignment correspond to the lower interval, in which the values are closer to 0 . In the same way, the kernel density estimates (Tables S2 and S3) of the generic-protection trees (bottom left) and 
of the local-interest trees are represented (bottom right). This means of representation allows one to observe, in greater detail, the spatial differences in the locations of the specimens.

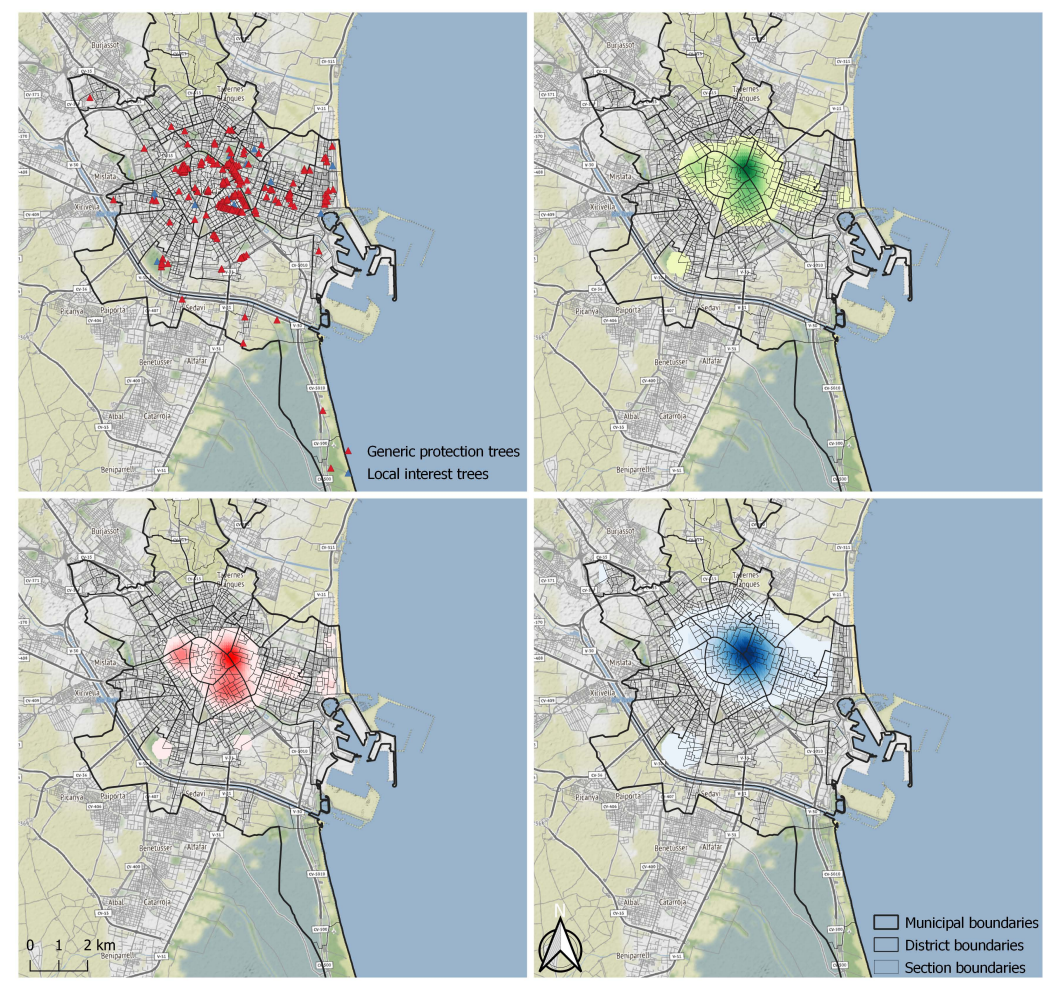

Figure 2. Spatial distribution of monumental trees (top left), and gaussian kernel density estimates with bandwidth selection based on cross-validation likelihood of total trees (top right), generic-protection trees (bottom left) and local-interest trees (bottom right).

As can be seen, the area with the highest density extends around the boundaries of the Ciutat Vella, Eixample, Pla del Real and La Saïdia districts, which are contiguous with one another. A high concentration of trees is also located in the axes constituted by the Gran Vía del Marqués del Turia and the Avenida Reino de Valencia. In the case of generic-protection trees, there is also a notable concentration in the Botanical Garden, located in the Extramurs district.

\subsection{Data and Methods}

One of the main purposes of this work was to compare the spatial distribution of monumental trees with that of different population groups, to determine whether there were spatial location patterns of the population related to high-value green spaces, represented, in this case, by monumental trees. That would demonstrate the existence of a relationship between the location of green infrastructures and environmental inequality in the city. In particular, we considered the relative weight (in \%) of three population groups defined according to demographic and socioeconomic criteria: the population with incomes per consumption unit above $200 \%$ of the median, single-person households, and the population aged 65 or over (Table S4). Thus, to assess the extent to which the relative weight of each population group was distributed following a spatial-clustering pattern, dispersion or randomness, we used Moran's I Index [25]. This statistic of spatial autocorrelation is particularly useful for assessing the similarity in the socio-residential composition of each census tract with respect to its closest environment. The values obtained by the indicator range from -1 (maximum negative autocorrelation) to 1 (maximum positive autocorrelation), with 0 indicating the absence of autocorrelation or randomness.

This autocorrelation, however, is global and does not inform about the spatial heterogeneity present between territorial units. For this reason, we also use the local version of this indicator: the local Moran's index [26]. For a better interpretation, statistically significant clusters were represented in 
Local Indicators of Spatial Association (LISA) maps. The clusters of census sections with the highest weight of each population group were identified with the High-High typology; the clusters with the lowest weight were identified as Low-Low, and the Low-High and High-Low types indicated that the statistical relationship between the values of the reference section and the neighbouring sections was negative. Statistically non-significant results are represented in white.

In the framework of the Exploratory Spatial Data Analysis (ESDA), the use of both indicators together is remarkably widespread in the literature and has been frequently applied in order to analyse the spatial distribution patterns of a wide range of cases, such as the locations of the Airbnbs [27,28], evictions [29,30], foreign population [31,32], or wage income [33].

To more rigorously assess the bivariate statistical association between the density-estimate spatial distribution and that of the different population groups, we used Pearson's r correlation coefficient, the bivariate version of the global Moran's index $\left(\mathrm{I}_{\mathrm{B}}\right)$ and the $\mathrm{L}_{X, Y}$ statistic from Lee [34]. Pearson's $\mathrm{r}$ coefficient is configured as a non-spatial bivariate measure of association, while the remaining two statistics present an intrinsically geographical formulation. Thus, $\mathrm{I}_{\mathrm{B}}$ represents an extension of the univariate index logic to the relationship between two different variables. In essence, this procedure captures the relationship between the value of one variable at location $i, x_{i}$, and the average of the neighbouring values $j$ for another variable $y$. However, this measure must be interpreted with some caution, since, unlike in the case of Pearson's $r$ coefficient, it does not consider the in situ correlation between the two variables but rather that between a variable in the reference place and another spatially "lagged" variable [35]. For its part, the $\mathrm{L}_{X, Y}$ statistic represents a methodological integration of Pearson's r coefficient and global Moran's index.

As in the previous case, these statistics are global in nature and do not report on the spatial heterogeneity implicit in the relationships between variables. In the case of the $\mathrm{I}_{\mathrm{B}}$, its local version follows a logic very similar to that of the local autocorrelation statistic, but including a second "lagged" variable instead of the reference variable. In a similar way to that described above, the identification of "hot spots" was carried out by representing LISA cluster maps. For its part, the local version of the $\mathrm{L}_{X, Y}$ statistic by $L_{e e}, L_{i}$, indicates the relative contribution of an individual area to the global $L_{X, Y}$ statistic and also allows exploring the spatial heterogeneity derived from local instability in the relationships between two variables [34].

The implementation of the proposed measures faces the problem of the data's statistical aggregation to the same territorial unit. Thus, values from the kernel-density estimates were aggregated to a grid of cells homogenously distributed in space, while the variables relative to the different population groups were aggregated at the census-section level. To overcome this problem, the grid of cells and the polygons corresponding to the census sections were intersected, and the values of the density estimates were averaged for each census section to which they belonged (Table S4). One of the main advantages of the kernel-density estimate is that it produces a spatial isotropic smoothing, which, in this case, can be interpreted as a "zone of proximity", with intensity based on location density. In this sense, the aggregation of the average values to the census section to which they belong does not produce notable biases when the territorial unit has a small size, not much larger than the cells of the grid.

Population-group data were obtained from the Household Income Distribution Atlas, published by the INE [36]. The geolocation of the generic-protection trees was possible thanks to the Catalogue of Monumental Trees, which contains the coordinates of each specimen. For its part, the geolocation of the local-interest trees came from the open-data website of the Valencia City Council [37].

All the maps presented in this paper were prepared using the free software QGIS 3.10. The kernel-density estimates were implemented using the R package "spatstat" [38,39]. The calculation of the I and $\mathrm{I}_{\mathrm{B}}$ statistics was carried out using the free software GeoDa 1.14 [40]. Finally, the values of the Lee statistics were calculated using the R package "spdep" [41,42]. 


\section{Results}

Figures 3-5 present the quintile maps (on the left) of the spatial distribution of the relative weight (in \%) of each population group and its corresponding LISA cluster map (on the right). The values of the global I are 0.707 for the population with incomes per unit of consumption above $200 \%$ of the median, 0.502 for single-person households and 0.313 for the population aged 65 or over. The population with incomes per unit of consumption above $200 \%$ of the median shows the highest degree of spatial autocorrelation, followed by single-person households and the population aged 65 or over, which indicates that socioeconomic status is the element with the greatest impact on the socio-residential articulation of the Valencian population.

Compared with the kernel-density maps of monumental trees (Figure 2), LISA cluster maps suggest a certain positive relationship between the spatial distribution of the monumental trees and that of the different population groups, particularly evident in the case of the population with incomes per consumption unit above $200 \%$ of the median. The spatial distribution of this population group (Figure 3) is characterized by the formation of High-High-type clusters in most of the sections belonging to the districts of Ciutat Vella, L'Eixample, Extramurs and Pla del Real, as well as in the neighbourhoods of Penya-Roja (Camins al Grau district), Trinitat (La Saïdia), Benimaclet, Sant Pau (Campanar) and La Carrasca (Algirós). Low-Low-type clusters are mainly distributed in peripheral areas, covering part of the Benicalap, Rascanya, Patraix and Jesús districts, and several neighbourhoods of Pobles del Sud, Quatre Carreres and L'Olivereta districts, Malvarrosa - Cabanyal (Poblats Marítms) and Benimàmet (Pobles de l'Oest).
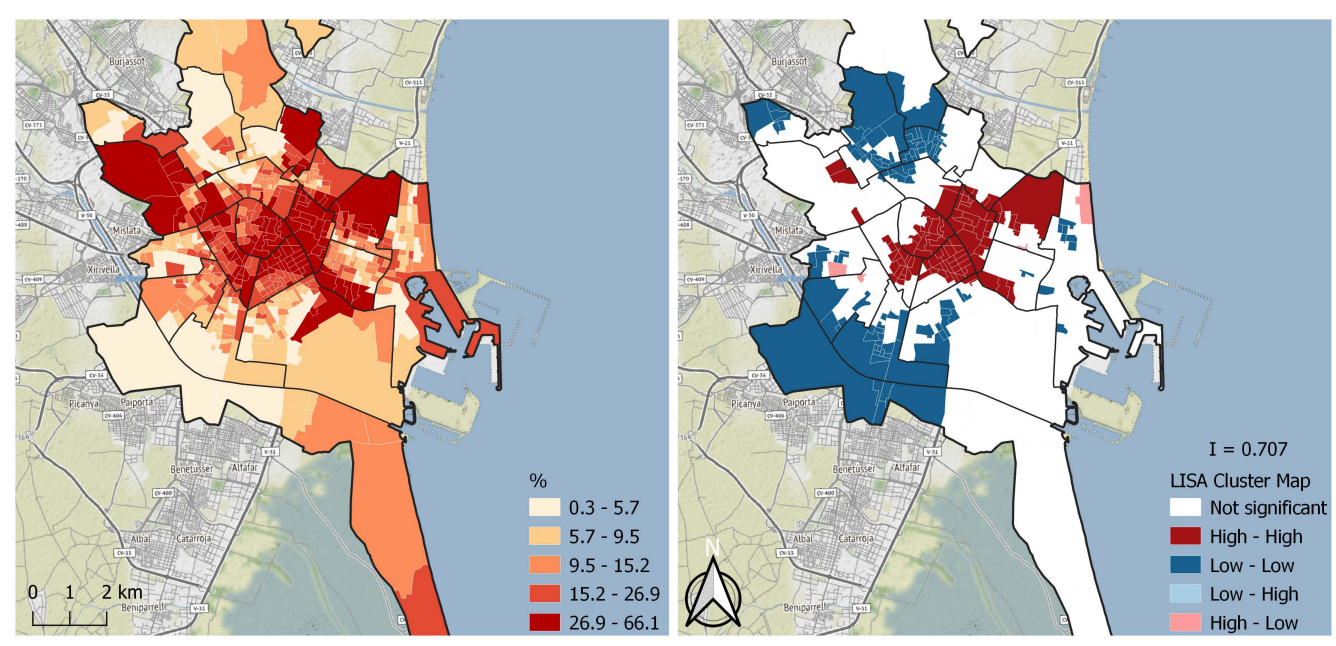

Figure 3. Quintile map of the distribution of the population with incomes per consumption unit above $200 \%$ of the median (in \%) (left), and Local Indicators of Spatial Association (LISA) cluster map (right).

The spatial distribution of single-person households (Figure 4) leads to the formation of High-High-type clusters mainly in Ciutat Vella and in several neighbourhoods of the expansions belonging to the Extramurs and Eixample (Russafa neighbourhood) districts. High-High-type clusters are also located in the neighbourhoods of Morvedre (La Saïdia), Ciutat Jardí (Algirós) and Cabanyal-Canyamelar (Poblats Marítims). Low-Low-type clusters are distributed peripherally, following a centrifugal spatial projection. 


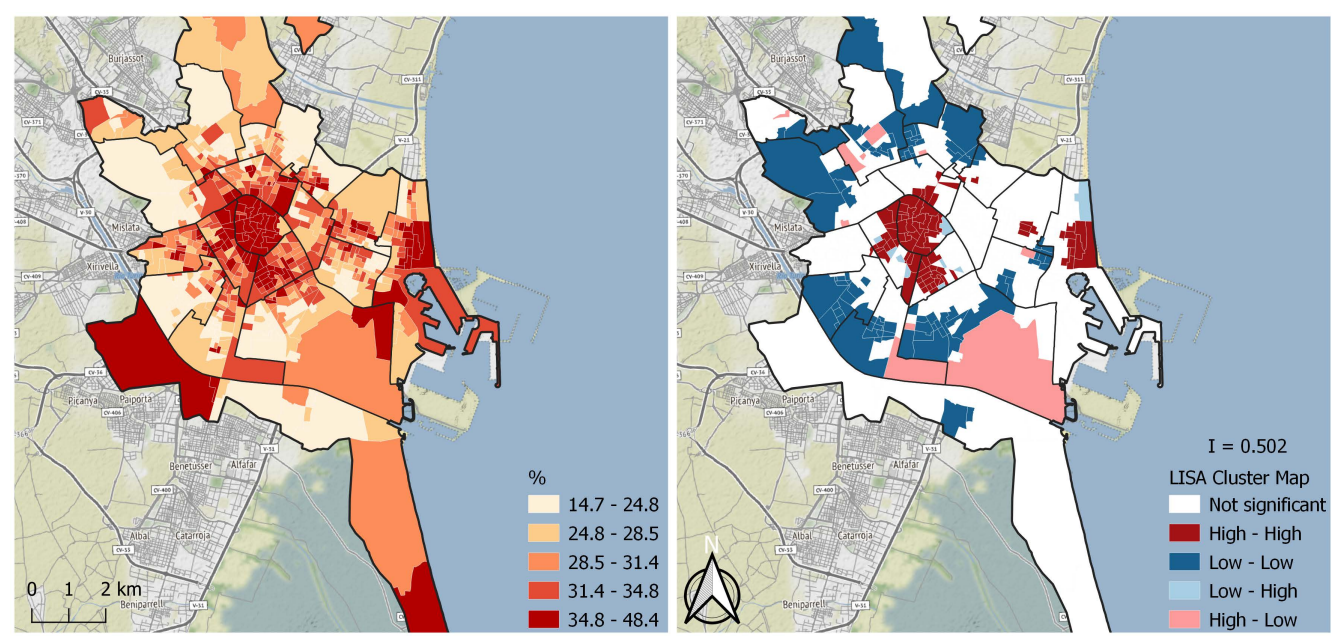

Figure 4. Quintile map of the distribution of the single-person households (in \%) (left), and LISA cluster map (right).

The population aged 65 and over, for its part, shows its own differentiated territorial projection with respect to the previous population groups (Figure 5). High-High-type clusters are more dispersed and smaller in size, but they are located mainly around the urban axis determined by the boundaries of the contiguous districts of Ciutat Vella, Eixample, Pla del Real and La Saïdia. High-High-type clusters are also located in several neighbourhoods of Patraix district, Campanar, Arrancapins (Extramurs), Ciutat Jardí (Algirós), Nou Moles (L'Olivereta) and Marxalenes (La Saïdia). Again, Low-Low-type clusters follow a peripheral territorial projection, although with a less marked pattern than in the case of single-person households.
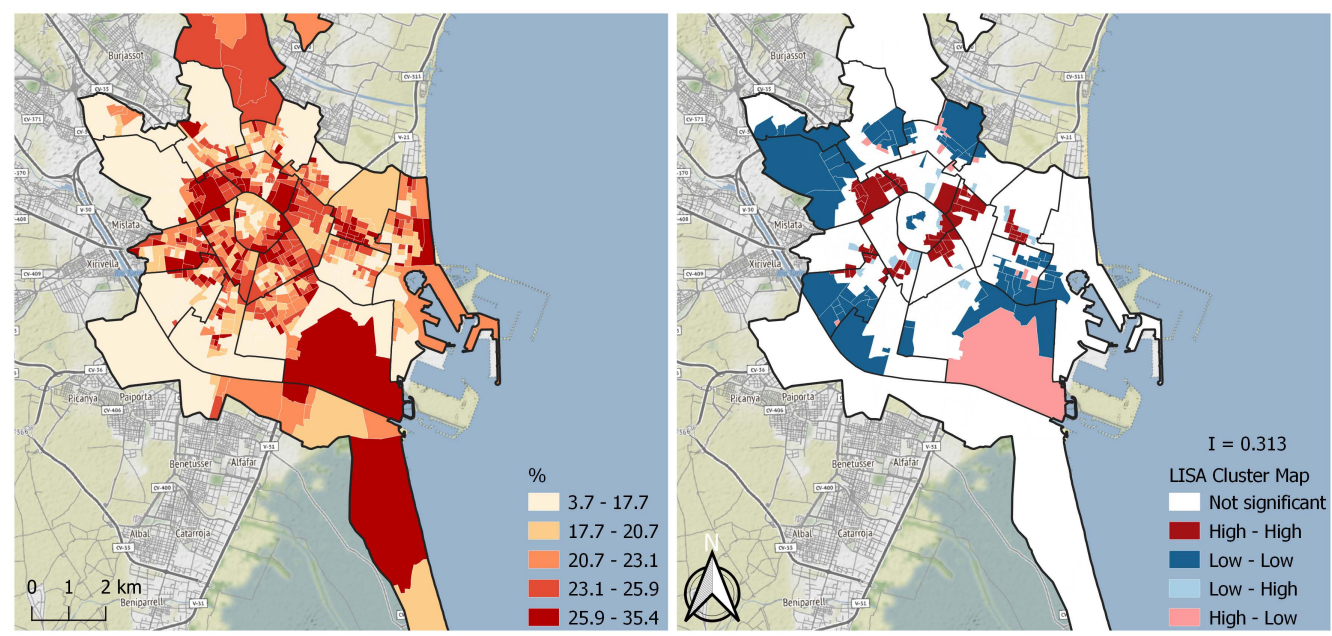

Figure 5. Quintile map of the distribution of the population aged 65 and over (in \%) (left), and LISA cluster map (right).

Table 1 presents the values of the different bivariate association statistics between the relative weight of each population group and the average kernel-density estimate, obtained by the method described in the previous section. The totality of monumental trees represented in Figure 2 (top left) are considered globally. The same measures of statistical association are applied with respect to the generic-protection trees and to the local-interest trees, considered separately. 
Table 1. Bivariate association statistics.

\begin{tabular}{|c|c|c|c|}
\hline Variables & $\mathbf{r}$ & $\mathbf{I}_{\mathbf{B}}$ & $\mathbf{L}_{X, Y}$ \\
\hline \multicolumn{4}{|l|}{ Monumental trees } \\
\hline Single-person households (\%) & $0.233 *$ & 0.241 * & 0.240 * \\
\hline Population aged 65 years or over $(\%)$ & $0.226^{*}$ & 0.200 * & $0.186^{*}$ \\
\hline Population with incomes above $200 \%$ of the median $(\%)$ & 0.644 * & 0.605 * & 0.582 * \\
\hline \multicolumn{4}{|l|}{ Generic protection trees } \\
\hline Single-person households (\%) & $0.249 *$ & $0.253 *$ & 0.249 * \\
\hline Population aged 65 years or over $(\%)$ & $0.211 *$ & 0.184 * & $0.172 *$ \\
\hline Population with incomes above $200 \%$ of the median (\%) & $0.608^{*}$ & 0.570 * & $0.548^{*}$ \\
\hline \multicolumn{4}{|l|}{ Local interest trees } \\
\hline Single-person households (\%) & $0.188 *$ & $0.195 *$ & 0.193 * \\
\hline Population aged 65 years or over $(\%)$ & $0.188 *$ & 0.174 * & 0.165 * \\
\hline Population with incomes above $200 \%$ of the median (\%) & $0.575^{*}$ & 0.551 * & $0.532 *$ \\
\hline
\end{tabular}

As can be seen, all the statistics are significant at 0.01 . The spatial distribution of monumental trees is more closely related to the population with incomes per unit of consumption above $200 \%$ of the median. This population group has a Pearson $r$ coefficient of 0.644 , an $\mathrm{I}_{\mathrm{B}}$ of 0.605 and an $\mathrm{L}_{X, Y}$ of 0.582 with respect to the average kernel-density estimate for monumental trees. Single-person households have an $\mathrm{r}$ of 0.233 , an $\mathrm{I}_{\mathrm{B}}$ of 0.241 and an $\mathrm{L}_{X, Y}$ of 0.24 . For its part, the population aged 65 and over has an $\mathrm{r}$ coefficient of 0.226 , an $\mathrm{I}_{\mathrm{B}}$ of 0.2 and an $\mathrm{L}_{X, Y}$ of 0.186 .

The results obtained indicate that the areas with the highest locational density of monumental trees and their neighbouring areas have a greater presence of high-income population. Conversely, areas with a lower locational density of monumental trees have a lower relative weight of high-income population. This association has a markedly higher intensity than that which exists between the locational density of monumental trees and the spatial distribution of the other two population groups, which indicates that the spatial-insertion pattern of monumental trees in the city of Valencia has some implications with respect to the socioeconomic characteristics of the population. For their part, single-person households and the population aged 65 or over also show a positive association with the density of monumental trees, although of a lower magnitude.

Comparing between protection typologies, the values corresponding to the different association statistics do not differ significantly, which indicates that the spatial patterns of monumental-tree protection followed by both levels of government have been similar. Although there is a slight decrease in the values of the statistics in the case of local-interest trees, this is probably an effect of the decrease in population size.

Figures 6-8 present the natural-breaks maps (on the left) of the spatial distribution of the local statistic $\mathrm{L}_{\mathrm{i}}$ (Table S5) for the association between each population group and the average kernel-density estimate, and the bivariate LISA cluster maps (right). As noted above, $\mathrm{L}_{\mathrm{i}}$ describes the relative contribution of an individual area to the global statistic and also allows exploring the spatial heterogeneity in the relationships between two variables. Figure 6 (left) clearly illustrates this property: the relative contribution of the $\mathrm{L}_{\mathrm{i}}$ statistic in the census sections located in the area with the highest locational density of monumental trees is notably greater than that in the rest of the cases, again accounting for the greater intensity of the association between the population of high socioeconomic status and the concentration of monumental trees. By comparison, the relative contribution of these census sections in the case of the variables single-person households (Figure 7 left) and elderly population (Figure 8 left) is notably lower. The local version of $\mathrm{I}_{\mathrm{B}}$, for its part, presents a spatial distribution similar to that of its univariate counterpart, as shown by the cluster maps. 

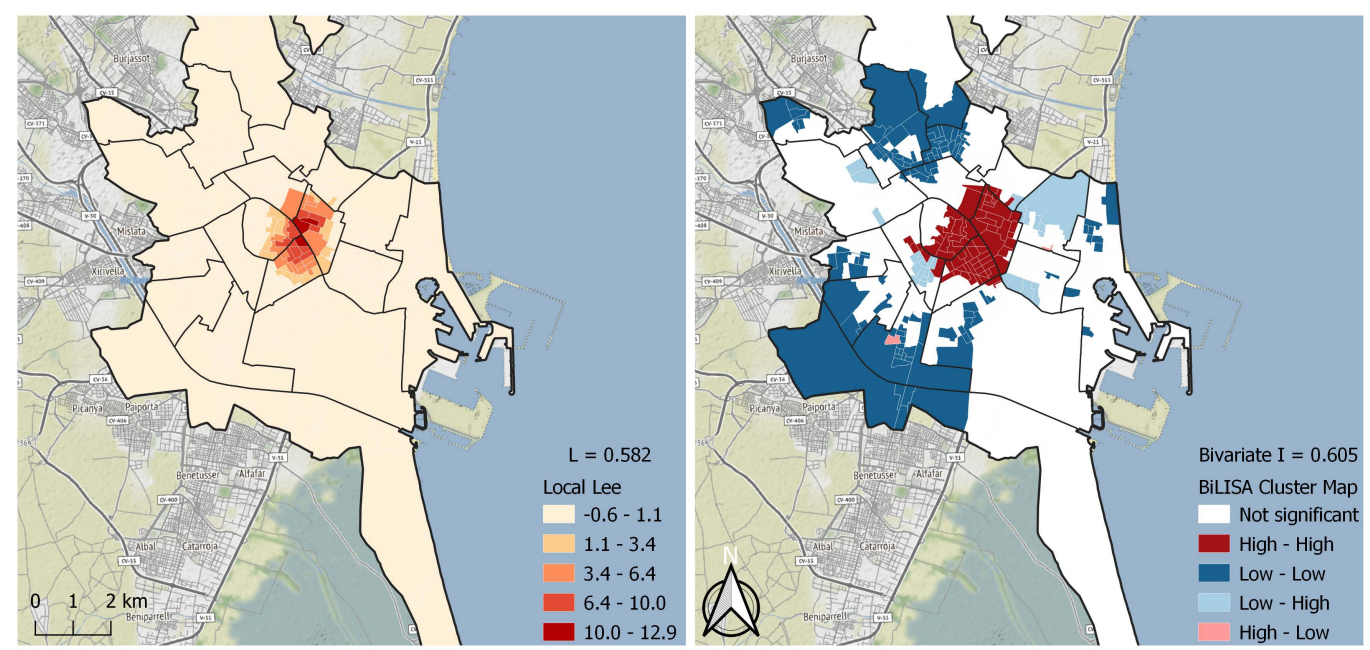

Figure 6. Association statistics between the average kernel-density estimate and the population with incomes per consumption unit above $200 \%$ of the median (in $\%$ ) $-\mathrm{L}_{\mathrm{i}}$ map of natural breaks (left) —and bivariate LISA cluster map (right).
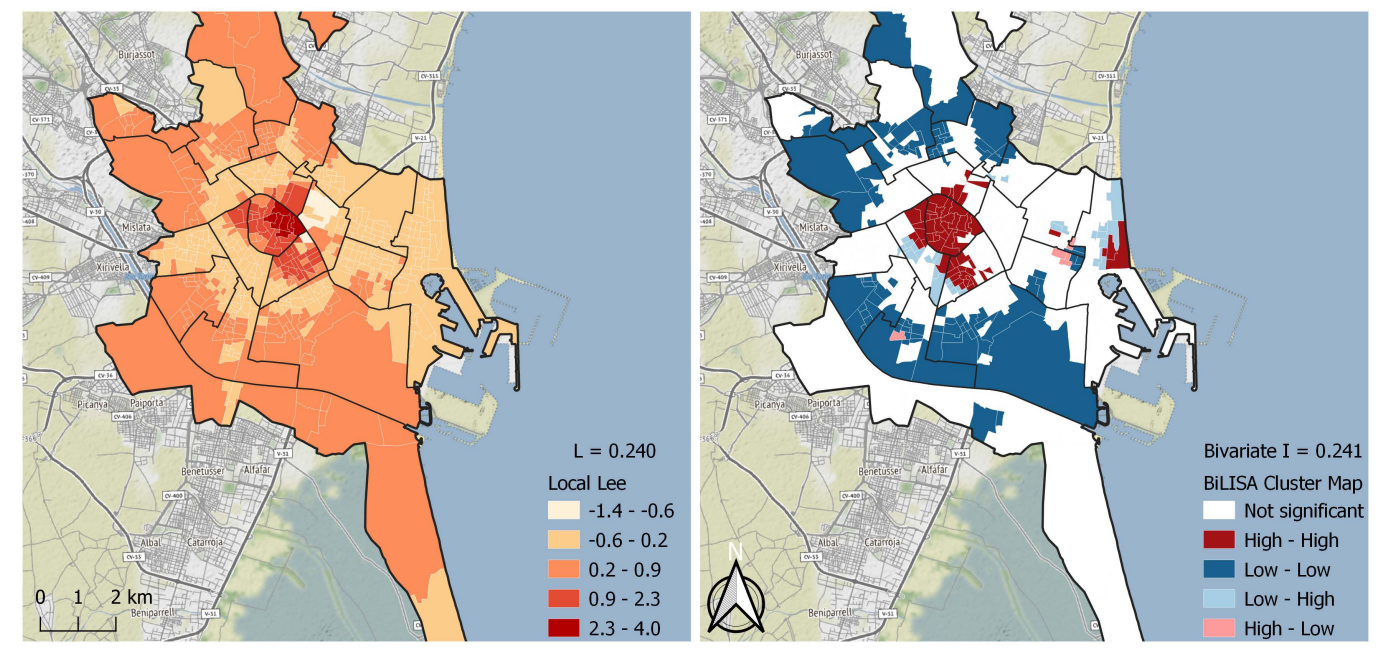

Figure 7. Association statistics between the average kernel-density estimate and the single-person households (in \%) - $\mathrm{L}_{\mathrm{i}}$ map of natural breaks (left)—and bivariate LISA cluster map (right).
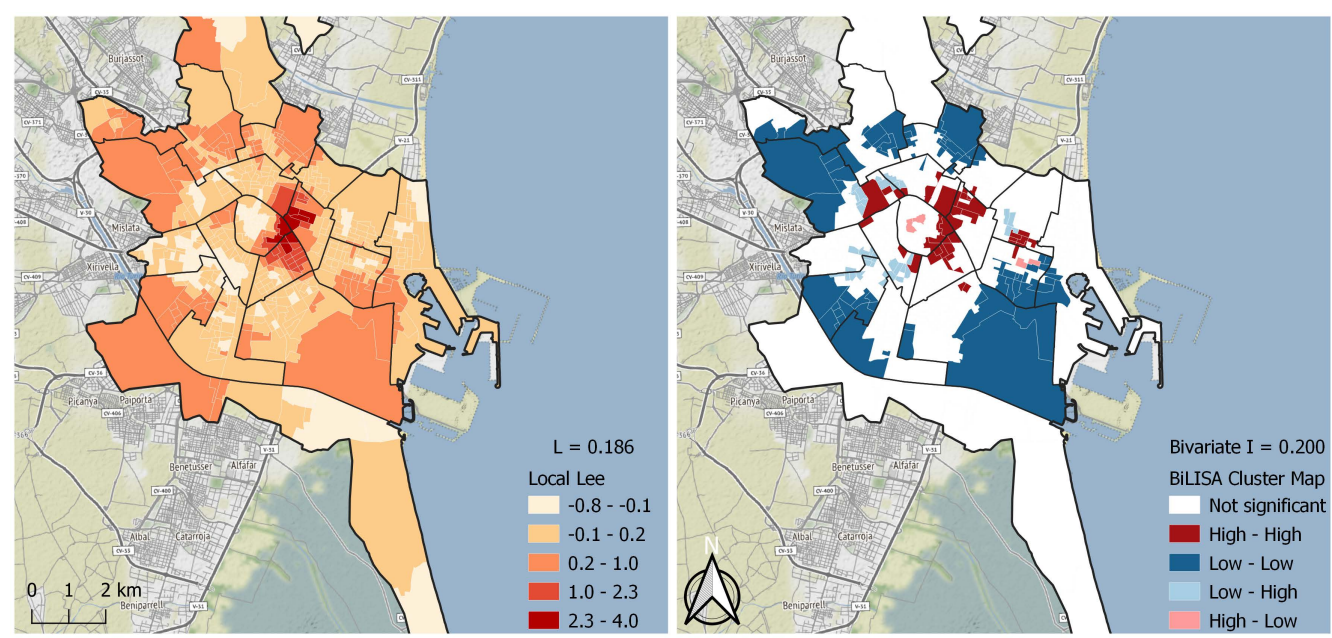

Figure 8. Association statistics between the average kernel-density estimate and the population aged 65 and over (in \%)— $\mathrm{L}_{\mathrm{i}}$ map of natural breaks (left)—and bivariate LISA cluster map (right). 


\section{Discussion}

As noted above, urban trees provide several ecosystem and social benefits. In addition, due to their size and particular biological and cultural characteristics, monumental trees garner great environmental interest. The results obtained in this research indicate that the areas with the highest density of monumental trees and their neighbouring areas have a greater presence of high-income population. The main outcome that these results suggest is that these ecosystem and social benefits could be unevenly distributed among the population, benefiting the high-income population to a greater extent.

The environmental-justice issue in urban settings has been widely analysed and discussed in the academic literature. Most studies reveal that green-space distribution often disproportionately benefits predominantly white and high-income communities [43]. However, the socio-spatial insertion of green areas in cities is shaped by multiple circumstances and particular contexts. This diversity of circumstances is exposed in several comparative studies that assess the environmental-justice issue in different cities.

As an illustration, Talen [44] analysed the equity of the US urban-park distribution in Macon (Georgia) and Pueblo (Colorado), comparing the spatial grouping of urban-park access scores with the spatial clustering of socioeconomic variables. The results showed a marked contrast between the two cases: in Macon, the spatial pattern of low accessibility corresponded to certain areas shaped by high housing values and low percentages of non-white residents, while in Pueblo, the inverse was true. In another more recent case comparison, Sousa Silva et al. [45] show the existence of inequalities in accessibility to green spaces linked to the ethnic composition of certain neighbourhoods in Tartu (Estonia) and Faro (Portugal). In Tartu, less accessibility was revealed in the Soviet-era housing districts, where a large part of the Russian minorities resides, while the Roma communities in Faro were located in districts without access to public green spaces. Other studies applied to Atlanta, Georgia, US [46], or Porto, Portugal [47], show a comparatively lower accessibility in socioeconomically disadvantaged areas.

As a key part of urban green infrastructure, the spatial distribution of urban trees determines how its ecosystem benefits are distributed among different population groups. The available empirical evidence shows that there is a relationship between the spatial distribution of urban trees and the socio-residential composition of the neighbourhood, which tends to penalize disadvantaged urban areas to a greater extent, highlighting yet another element in the urban social-inequality processes. Some case studies have assessed this relationship in very different cities. For example, in Boston, Massachusetts [5]; Milwaukee, Wisconsin [2]; Guadalajara, Mexico [8]; and Tampa, Florida [3], and regions such as the Eastern Cape, South Africa [4], different applied studies have revealed the existence of spatial inequalities in the provision of urban trees, which mainly fall on disadvantaged neighbourhoods. However, there are cities where this situation is not appreciated or the data are not conclusive. This is the case of Barcelona in Spain, where there is insufficient evidence of a significant and positive association between the distribution of low-income residents and a lower amount of benefits from urban trees [7]. This is also the case in cities in other countries, such as Boston (US), where the contrast between the results of some case studies yields an inconclusive picture about the nature of the relationship between the spatial distribution of urban trees and the sociodemographic composition of neighbourhoods [5,6].

The spatial distribution of the monumental trees and its link with high-income urban areas has certain implications in terms of socio-spatial justice. On the one hand, the special status of these trees could be framed in a broader set of green-intervention strategies, as part of urban public policies, focused on consolidating or reconfiguring the position of certain neighbourhoods in the urban spatial hierarchy, improving their tourist and socio-residential attractiveness and capturing high incomes. In this sense, green gentrification is defined as "new or intensified urban socio-spatial inequities produced by urban greening agendas and interventions, such as greenways, parks, community gardens, ecological corridors, or green infrastructure" [48]. 
There is a remarkable body of literature on the impact of green urban policies on the socio-residential fabric of neighbourhoods [43,49,50]. Different primary studies applied to cities such as Barcelona [51], Philadelphia [52] or Leipzig [53] show reconfigurations in the urban socio-spatial structure over time, as a direct or indirect consequence of green-intervention policies. This reconfiguration, however, does not always occur in a univocal sense. In the case of Barcelona, Anguelovski et al. [51] showed that new green spaces created during the 1990s and early 2000s in the historic complex and formerly industrialized neighbourhoods experienced a green-gentrification process, while most economically deprived areas and working-class neighbourhoods more isolated from the city centre gained vulnerable populations as they became greener. In Philadelphia, Pearsall and Eller [52] examined the gentrification patterns associated with eighteen new public green spaces created around 2010, noting that neighbourhoods with new public green spaces located near other gentrified neighbourhoods were more susceptible to gentrification than those located further afield, as well as that the green spaces created in gentrified neighbourhoods were less accessible than the new spaces created in richer and non-gentrifiable neighbourhoods. In Leipzig, Ali et al. [53] showed that the Lene-Voigt-Park case acted as a catalyst for a gentrification process triggered by the real-estate sector.

A fact that supports this approach is the planning, promotion and dissemination, by the local government, of several routes of monumental trees for tourist purposes. Likewise, the transplantation of several specimens has been a helping factor for the spatial concentration patterns of monumental trees. However, a distinction should be made between urban interventions specifically focused on modifying the socio-residential composition of neighbourhoods and those that exert this impact in a secondary way or as a by-product. The concept of green gentrification and its applicability should be treated with caution, as it could imply that urban greening itself can lead to or trigger gentrification and the displacement of vulnerable population groups [53].

Although the argument can be transferred in the same way, it is unrealistic to assume that, by itself, the declaration of monumentality can act as a catalyst for processes of gentrification or the consolidation of the socio-residential fabric of neighbourhoods. However, the spatial concentration of monumental trees and their relationship with high-income areas can constitute indicators of intervention priorities in the urban environment and the strategic framework of territorial public policies.

On the other hand, political-economic factors play a key role in the production of urban settings, even where urban trees are planted and or allowed to grow [2]. The urban-territorial development of the city of Valencia, together with the different land uses, has been a key element in the configuration of these patterns. Thus, the aesthetic, landscape, symbolic or environmental value of certain urban environments with greater socioeconomic status could be the fundamental cause of the greater number of trees located in these spaces declared monumental or included in the catalogue. In this sense, the greater spatial concentration of monumental trees in affluent neighbourhoods would only represent one more indicator of their position in the urban spatial hierarchy. In other words, the distribution of trees that meet the characteristics of monumentality is linked to urban public policies that have facilitated their strategic location and subsequent development, and would constitute a by-product of the inequalities that characterize the urban socio-spatial structure.

Both approaches are not intrinsically exclusive but rather mutually reinforce each other and make sense together.

\section{Conclusions}

This work aimed to analyse the spatial distribution patterns of the monumental-tree heritage in the city of Valencia in relation to different socioeconomic and demographic characteristics of the urban environment, in order to establish whether this distribution was linked to environmental and socio-spatial justice criteria. For this purpose, different ESDA and spatial-point-analysis techniques were implemented.

The geolocation of generic-protection trees and of local-interest trees showed that, in general terms, monumental trees present a higher locational density in certain areas of the city. These areas are 
made up, in comparative terms, of a larger population with high incomes. The bivariate statistical analysis revealed a remarkable and statistically significant relationship between the density of the spatial distribution of monumental trees and the population with incomes per consumption unit above $200 \%$ of the median. Likewise, the presence of monumental trees showed a statistically significant relationship, although of a lesser magnitude, with the population aged 65 years and over and with single-person households.

The intra-urban distribution of monumental trees constitutes an issue linked to the field of spatial justice. The fact that it has a significant relationship with the distribution of the high-income population can be seen from a double perspective. On the one hand, the protection of these trees could be part of a set of green-intervention strategies focused on consolidating or reconfiguring the position of certain neighbourhoods in the urban spatial hierarchy, which is known as "green gentrification". On the other hand, the aesthetic, landscape, symbolic or environmental value of certain urban environments with greater socioeconomic status could constitute the fundamental cause of there being more trees located in these spaces declared monumental or included in the catalogue. In this sense, the greater spatial concentration of monumental trees in affluent neighbourhoods would only constitute one more indicator of their position in the urban spatial hierarchy.

The main strength of this paper is that it shows a strong association between the spatial distribution of monumental trees and that of the high-income population. The results obtained have made it possible to describe the socio-spatial insertion of monumental trees in the city of Valencia and its relationship with environmental justice. Monumental trees are spatially concentrated in high-income neighbourhoods, and this fact represents an indicator of environmental inequality that penalizes the rest of the neighbourhoods that make up the socio-residential mosaic. Its main limitation, however, is that the methods used do not allow the estimation of to what extent each exposed involvement approaches reality, that is, if the uneven spatial distribution of the monumental trees constitutes one of the causes of the socio-spatial differentiation or, analogously, it constitutes an output of the historical and territorial patterns of green-intervention policies in high-status neighbourhoods. Future research should advance in this direction. Other interesting aspects to be addressed by the research would be the differential ecosystem and social benefits that, due to their particular characteristics, monumental trees would provide in relation to the rest of the urban trees; how they would contribute at the local level to mitigate the effects related to climate change; or, based on an economic analysis, their relationship, for example, with the sensitivity of the economic performance of the local companies to climate change [54].

This diagnosis can provide support for decision-making on this matter and particularly on those aspects related to distributive intervention in the urban environment. A more even distribution of monumental and singular trees could be more desirable, from the point of view of environmental and socio-spatial justice. However, this raises certain problems in terms of public intervention mechanisms.

One option would be to make the protection criteria more flexible so that more trees could be included in the protection framework. The outcomes of this policy, however, may not be clear. On the one hand, it could increase the dispersion of the spatial distribution of the monumental trees, due to the inclusion of trees further from the centre, expansions, and areas with greater historical and territorial implantation, which could translate into greater evenness. On the other hand, it could increase the concentration of trees declared monumental in green spaces located in areas of high socioeconomic status, which would worsen the starting situation. Posing a redistribution scenario, however, is outside the scope of this research.

Another option would be to improve the governance network for monumental trees, so that both associations and citizens become more involved in the processes of declaration of monumentality. Although the law currently provides for a request for the express protection of monumental trees by interested persons or entities, it does not structure an authentic channel for citizen participation. The city of Valencia has advanced in this direction by creating a Municipal Tree Observatory, which has promoted participation in the protection framework for monumental trees. However, in general, it continues to be a poorly institutionalized process. 
These suggestions, however, would not represent any improvement over the starting situation if the distribution of the urban green infrastructure were notably uneven or there was a marked contrast in the physical and social environment between the different neighbourhoods. Therefore, rebalancing the spatial distribution of urban greenery or preventing the physical and social degradation of neighbourhoods through green-intervention policies and avoiding abrupt socio-spatial transformations that could lead to gentrification are good options for environmental and socio-spatial justice. It is hard to improve the evenness of the spatial distribution of monumental trees if the distribution of urban greenery or urban historical development is deeply uneven.

Supplementary Materials: The following are available online at http:/www.mdpi.com/2071-1050/12/18/7760/s1. Table S1: Total trees density; Table S2: Generic protection trees density; Table S3: Local interest trees density; Table S4: VLC Sections Attributes; Table S5: Local Lee; Shapefile S1: VLC; Shapefile S2: total_trees; Shapefile S3: generic_protect; Shapefle S4: local_interest.

Author Contributions: Conceptualization, A.G.-V. and F.R.-R.; methodology, A.G.-V.; software, A.G.-V.; validation, A.G.-V.; formal analysis, A.G.-V.; investigation, A.G.-V. and F.R.-R.; resources, A.G.-V.; data curation, A.G.-V.; writing—original draft preparation, A.G.-V and F.R.-R.; writing—review and editing, F.R.R. and J.G.-F.; visualization, A.G.-V.; supervision, F.R.-R. and J.G.-F.; project administration, F.R.-R. and J.G.-F. All authors have read and agreed to the published version of the manuscript.

Funding: This research received no external funding.

Conflicts of Interest: The authors declare no conflict of interest.

\section{References}

1. Harner, J.; Warner, K.; Pierce, J.; Huber, T. Urban environmental justice indices. Prof. Geogr. 2002, 54, 318-331. [CrossRef]

2. Heynen, N.; Perkins, H.A.; Roy, P. The Political Ecology of Uneven Urban Green Space: The Impact of Political Economy on Race and Ethnicity in Producing Environmental Inequality in Milwaukee. Urban Aff. Rev. 2006, 42, 3-25. [CrossRef]

3. Landry, S.M.; Chakraborty, J. Street Trees and Equity: Evaluating the Spatial Distribution of an Urban Amenity. Environ. Plan. A Econ. Space 2009, 41, 2651-2670. [CrossRef]

4. Kuruneri-Chitepo, C.; Shackleton, C.M. The distribution, abundance and composition of street trees in selected towns of the Eastern Cape, South Africa. Urban For. Urban Green. 2011, 10, 247-254. [CrossRef]

5. Danford, R.; Cheng, C.; Strohbach, M.; Ryan, R.; Nicolson, C.; Warren, P. What Does It Take to Achieve Equitable Urban Tree Canopy Distribution? A Boston Case Study. Cities Environ. 2014, 7, 2.

6. Duncan, D.T.; Kawachi, I.; Kum, S.; Aldstadt, J.; Piras, G.; Matthews, S.A.; Arbia, G.; Castro, M.C.; White, K.; Williams, D.R. A spatially explicit approach to the study of socio-demographic inequality in the spatial distribution of trees across Boston neighbourhoods. Spat. Demogr. 2014, 2, 1-29. [CrossRef]

7. Baró, F.; Calderón-Argelich, A.; Langemeyer, J.; Connolly, J.J.T. Under one canopy? Assessing the distributional environmental justice implications of street tree benefits in Barcelona. Environ. Sci. Policy 2019, 102, 54-64. [CrossRef]

8. Cruz-Sandoval, M.; Ortego, M.I.; Roca, E. Tree Ecosystem Services, for Everyone? A Compositional Analysis Approach to Assess the Distribution of Urban Trees as an Indicator of Environmental Justice. Sustainability 2020, 12, 1215. [CrossRef]

9. Bowler, D.E.; Buyung-Ali, L.; Knight, T.M.; Pullin, A.S. Urban greening to cool towns and cities: A systematic review of the empirical evidence. Landsc. Urban Plan. 2010, 97, 147-155. [CrossRef]

10. Gillner, S.; Vogt, J.; Tharang, A.; Dettmann, S.; Roloff, A. Role of street trees in mitigating effects of heat and drought at highly sealed urban sites. Landsc. Urban Plan. 2015, 143, 33-42. [CrossRef]

11. Nowak, D.J.; Crane, D.E.; Stevens, J.C. Air pollution removal by urban trees and shrubs in the United States. Urban For. Urban Green. 2006, 4, 115-123. [CrossRef]

12. Berland, A.; Shiflett, S.A.; Shuster, W.D.; Garmestani, A.S.; Goddard, H.C.; Herrmann, D.L.; Hopton, M.E. The role of trees in urban stormwater management. Landsc. Urban Plan. 2017, 162, 167-177. [CrossRef] [PubMed]

13. Alvey, A.A. Promoting and preserving biodiversity in the urban forest. Urban For. Urban Green. 2006, 5, 195-201. [CrossRef] 
14. Nesbitt, L.; Hotte, N.; Barron, S.; Cowan, J.; Sheppard, S.R. The social and economic value of cultural ecosystem services provided by urban forests in North America: A review and suggestions for future research. Urban For. Urban Green. 2017, 25, 103-111. [CrossRef]

15. Ramón Fernández, F. La protección del patrimonio arbóreo monumental en la legislación española. Su aplicación al turismo y al paisaje. Ius Et Prax. 2018, 24, 109-132. [CrossRef]

16. Ministerio de Fomento. Áreas Urbanas en España 2018: Cuarenta Años de las Ciudades Españolas; Ministerio de Fomento: Madrid, Spain, 2018.

17. Prytherch, D.L.; Boira Maiques, J.V. City profile: Valencia. Cities 2009, 26, 103-115. [CrossRef]

18. Alcalá-Santaella, F.; Díaz Orueta, F.; Ginés, X.; Lourés, M.L. Valencia. In Políticas Urbanas en España: Grandes Ciudades, Actores y Gobiernos Locales; Iglesias, M., Costa, M.M., Subirats, J., Tomàs, M., Eds.; Icaria: Barcelona, Spain, 2011; pp. 201-227.

19. Campos, B.S. Cabanyal, cada vez más cerca. Del lugar al espacio como mercancía. Zainak. Cuad. Antropol.-Etnogr. 2009, 32, 915-931.

20. Romero Renau, L.; Trudelle, C. Mega Events and Urban Conflicts in Valencia, Spain: Contesting the New Urban Modernity. Urban Stud. Res. 2011, 2011, 587523. [CrossRef]

21. Romero Renau, L.; Martín, L.L. De barrio-problema a barrio de moda: Gentrificación comercial en Russa-fa, El “Soho" valenciano. An. De Geogr. De La Univ. Complut. 2015, 35, 187-212. [CrossRef]

22. Esteve, A.J.B.; Arnandis-i-Agramunt, R. Touristificacion in the Central Market of Valencia: Fact or Fiction? In Handbook of Research on the Impacts, Challenges, and Policy Responses to Overtourism; Ribeiro de Almeida, C., Quintano, A., Simancas, M., Huete, R., Breda, Z., Eds.; IGI Global: Hershey, PA, USA, 2020; pp. 156-175. [CrossRef]

23. Duin, R.P.W. On the Choice of Smoothing Parameters for Parzen Estimators of Probability Density Functions. IEEE Trans. Comput. 1976, C-25, 1175-1179. [CrossRef]

24. Habbema, J.; Hermans, J.; van den Broek, K. A stepwise discriminant analysis program using density estimation. In COMPSTAT 1974; Bruckmann, G., Ed.; Physica: Vienna, Austria, 1974; pp. 101-110.

25. Moran, P.A.P. The Interpretation of Statistical Maps. J. R. Stat. Soc. Ser. B (Methodol.) 1948, 10, $243-251$. [CrossRef]

26. Anselin, L. Local Indicators of Spatial Association-LISA. Geogr. Anal. 1995, 27, 93-115. [CrossRef]

27. Gutiérrez, J.; García-Palomares, J.C.; Romanillos, G.; Salas-Olmedo, M.H. The eruption of Airbnb in tourist cities: Comparing spatial patterns of hotels and peer-to-peer accommodation in Barcelona. Tour. Manag. 2017, 62, 278-291. [CrossRef]

28. Lagonigro, R.; Martori, J.C.; Apparicio, P. Understanding Airbnb spatial distribution in a southern European city: The case of Barcelona. Appl. Geogr. 2020, 115, 102136. [CrossRef]

29. Gutiérrez, A.; Delclòs, X. The uneven distribution of evictions as new evidence of urban inequality: A spatial analysis approach in two Catalan cities. Cities 2016, 56, 101-108. [CrossRef]

30. Gutiérrez, A.; Domènech, A. The mortgage crisis and evictions in Barcelona: Identifying the determinants of the spatial clustering of foreclosures. Eur. Plan. Stud. 2018, 26, 1939-1960. [CrossRef]

31. Martori Cañas, J.; Hoberg, K. Nuevas Técnicas de Estadística Espacial para la Detección de Clusters Residenciales de Población Inmigrante. Scripta Nova. Revista Electrónica de Geografía y Ciencias Sociales. 2018, 12. Available online: https://revistes.ub.edu/index.php/ScriptaNova/article/view/1409 (accessed on 3 August 2020).

32. Rivas, J.J.N. Foreing Population in Málaga. Evolution of It's Residential Differentiation Levels and Trends of Spatial Distribution (2003/2010). Scripta Nova. Revista Electrónica de Geografía y Ciencias Sociales. 2012, 16. Available online: http://www.ub.es/geocrit/sn/sn-413.htm (accessed on 3 August 2020).

33. Madariaga, R.; Martori, J.C.; Oller, R. Spatial Distribution and Inequality of Wage Income in the Barcelona Metropolitan Area. Scripta Nova. Revista Electrónica de Geografía y Ciencias Sociales. 2012, 16. Available online: http://www.ub.es/geocrit/sn/sn-405.htm (accessed on 3 August 2020).

34. Lee, S.I. Developing a bivariate spatial association measure: An integration of Pearson's r and Moran's I. J. Geogr. Syst. 2001, 3, 369-385. [CrossRef]

35. Anselin, L.; Syabri, I.; Smirnov, O. Visualizing Multivariate Spatial Correlation with Dynamically Linked Windows; University of California: Santa Barbara, CA, USA, 2002; CD-ROM.

36. Atlas de Distribución de Renta de los Hogares. Available online: https://www.ine.es/experimental/atlas/exp_ atlas_tab.htm (accessed on 8 August 2020). 
37. Portal de Transparencia y Datos Abiertos Valencia. Available online: http://gobiernoabierto.valencia.es/es/ (accessed on 8 August 2020).

38. Baddeley, A.; Turner, R. spatstat: An R Package for Analyzing Spatial Point Patterns. J. Stat. Softw. 2005, 12, 1-42. [CrossRef]

39. Baddeley, A.; Rubak, E.; Turner, R. Spatial Point Patterns: Methodology and Applications with R; Chapman and Hall/CRC Press: London, UK, 2015.

40. Anselin, L.; Syabri, I.; Kho, Y. GeoDa: An Introduction to Spatial Data Analysis. Geogr. Anal. 2006, 38, 5-22. [CrossRef]

41. Bivand, R.; Pebesma, E.; Gomez-Rubio, V. Applied Spatial Data Analysis with R, 2nd ed.; Springer: New York, NY, USA, 2013.

42. Bivand, R.; Wong, D.W.S. Comparing implementations of global and local indicators of spatial association. TEST 2018, 27, 716-748. [CrossRef]

43. Wolch, J.R.; Byrne, J.; Newell, J.P. Urban green space, public health, and environmental justice: The challenge of making cities 'just green enough'. Landsc. Urban Plan. 2014, 125, 234-244. [CrossRef]

44. Talen, E. The Social Equity of Urban Service Distribution: An Exploration of Park Access in Pueblo, Colorado, and Macon, Georgia. Urban Geogr. 1997, 18, 521-541. [CrossRef]

45. Sousa Silva, C.; Viegas, I.; Panagopoulos, T.; Bell, S. Environmental justice in accessibility to green infrastructure in two European cities. Land 2018, 7, 134. [CrossRef]

46. Dai, D. Racial/ethnic and socioeconomic disparities in urban green space accessibility: Where to intervene? Landsc. Urban Plan. 2011, 102, 234-244. [CrossRef]

47. Hoffimann, E.; Barros, H.; Ribeiro, A.I. Socioeconomic inequalities in green space quality and accessibility—Evidence from a Southern European city. Int. J. Environ. Res. Public Health 2017, $14,916$. [CrossRef]

48. Anguelovski, I.; Connolly, J.J.T.; Garcia-Lamarca, M.; Cole, H.; Pearsall, H. New scholarly pathways on green gentrification: What does the urban «green turn» mean and where is it going? Progress Hum. Geogr. 2019, 43, 1064-1086. [CrossRef]

49. Pearsall, H.; Anguelovski, I. Contesting and resisting environmental gentrification: Responses to new paradoxes and challenges for urban environmental justice. Sociol. Res. Online 2016, 21, 121-127. [CrossRef]

50. Bockarjova, M.; Botzen, W.J.W.; van Schie, M.H.; Koetse, M.J. Property price effects of green interventions in cities: A meta-analysis and implications for gentrification. Environ. Sci. Policy 2020, 112, 293-304. [CrossRef]

51. Anguelovski, I.; Connolly, J.J.T.; Masip, L.; Pearsall, H. Assessing green gentrification in historically disenfranchised neighbourhoods: A longitudinal and spatial analysis of Barcelona. Urban Geogr. 2018, 39, 458-491. [CrossRef]

52. Pearsall, H.; Eller, J.K. Locating the green space paradox: A study of gentrification and public green space accessibility in Philadelphia, Pennsylvania. Landsc. Urban Plan. 2020, 195, 103708. [CrossRef]

53. Ali, L.; Haase, A.; Heiland, S. Gentrification through Green Regeneration? Analyzing the Interaction between Inner-City Green Space Development and Neighbourhood Change in the Context of Regrowth: The Case of Lene-Voigt-Park in Leipzig, Eastern Germany. Land 2020, 9, 24. [CrossRef]

54. Aldieri, L.; Vinci, C.P. Climate change and knowledge spillovers for cleaner production: New insights. J. Clean. Prod. 2020, 271, 122729. [CrossRef]

(C) 2020 by the authors. Licensee MDPI, Basel, Switzerland. This article is an open access article distributed under the terms and conditions of the Creative Commons Attribution (CC BY) license (http://creativecommons.org/licenses/by/4.0/). 